\author{
V. Folomeev ${ }^{1,2^{*}}$, B. Kleihaus ${ }^{3}$, J. Kunz ${ }^{3}$ \\ ${ }^{1}$ Academician J. Jeenbaev Institute of Physics of the NAS of the Kyrgyz Republic, Kyrgyzstan, Bishkek, \\ ${ }^{2}$ International Laboratory for Theoretical Cosmology, Tomsk State University \\ of Control Systems and Radioelectronics (TUSUR), Russia, Tomsk \\ ${ }^{3}$ Institut für Physik, Universität Oldenburg, Germany, Oldenburg, \\ *e-mail: vfolomeev@mail.ru
}

\title{
MIXED STAR-PLUS-WORMHOLE SYSTEMS WITH A COMPLEX SCALAR FIELD
}

We study compact mixed configurations with a nontrivial wormholelike spacetime topology supported by a complex ghost scalar field with a quartic self-interaction and a polytropic fluid. The latter is modeled by a relativistic barotropic equation of state that can approximately describe more or less realistic matter. For such systems, we find regular asymptotically flat equilibrium solutions describing localized configurations in which the fluid is concentrated in a finite-size region. The solutions obtained describe double-throat wormholes which are located outside the fluid (one can say that the fluid is hidden inside the region between the throats). Also, we consider the dependence of the total mass of the system on the central density of the fluid and demonstrate the existence of critical values of the central density at which the mass diverges. In this case all regular solutions possessing finite masses lie in the region between these critical values, and this region also contains a discontinuity in magnitudes of the central density where only physically unacceptable oscillating solutions do exist. Is shown that for some values of the central density of the fluid there can exist solutions describing systems whose fluid density and pressure maxima lie not at the center. This results in the fact that such systems possess two equators (local maxima of the metric function) resided symmetrically with respect to the center.

Key words: wormholes, nontrivial topology, complex scalar fields, polytropic fluid.

$$
\text { В. Фоломеев }{ }^{1,2^{*}} \text {, Б. Клейхаус }{ }^{3}, \text { Ж. Кунц }{ }^{3}
$$

${ }^{1}$ Қырғыз Республикасы ҰҒА академигі Ж. Жээнбаев атындағы физика институты, Қырғызстан, Бішкек к., ${ }^{2}$ Теориялық, космологияның халықаралық, зертханасы, Томск мемлекеттік басқару жүйелері және радиоэлектроника университеті (TUSUR), Ресей, Томск к. 3Физика институты, Ольденбург университеті, Германия, Ольденбург қ. *e-mail: vfolomeev@mail.ru

\section{Жұлдыз және көртышқан іні бар кешенді скалярлы өрісті аралас жүйелер}

Төрттік потенциалдық энергия және политропиялық сұйықтықпен кешенді скалярлы өріспен құрылған, бейтараптық, көртышқан іні тәрізді типтегі кеңістік-уақыттық топологиямен ықшам аралас конфигурацияларды зерттейміз. Бұл конфигурация релятивистік баротропиялық, теңдеумен моделденеді, ол нақтыланған затты сипаттай алады. Мұндай жүйелер үшін біз тұрақты асимптотикалық, жазық, тепе-теңдік шешімдерін табамыз және олар ішінара сұйықтыққа толы екі өңеші бар көртышқан індерді сипаттайтынын көрсетеміз. Алынған шешімдер сұйықтықтың сыртында орналасқан екі өңеші бар көртышқан інін сипаттайды (сұйықтық өңеш арасындағы аймақта жасырылған деп айта аламыз). Сонымен қатар жүйенің жалпы массасының сұйықтықтың орталық тығыздығына тәуелділігін қарастырамыз және масса таралатын орталық тығыздықтың критикалықммәндерінің бар екендігін көрсетеміз. Бұлжағдайда соңғымассалары бар барлық тұрақты шешімлер аймақта критикалық мәндер арасында орналасады және бұл аймақта тек физикалық жол берілмейтін тербелмелі шешімдер болатын орталық тығыздықтың мәндерінде тұрақсыздық бар. Сұйықтың орталық тығыздығының кейбір мәндері үшін сұйықтықтың тығыздығы мен оның қысымы максимумы конфигурацияның ортасында болмайтын жүйелерді сипаттайтын шешімдер болуы мүмкін екендігі көрсетілген. Бұл мұндай жүйелерде орталықта симметриялы орналасқан екі экватордың (метрикалық функцияның жергілікті максимумы) болуына әкеледі.

Түйін сөздер: көртышқан іні, тривиалды емес топология, күрделі скалярлы өрістер, политропты сұйықтық. 


\title{
В. Фоломеев ${ }^{1,2^{*}}$, Б. Клейхаус ${ }^{3}$, Ж. Кунц ${ }^{3}$ \\ 'Институт физики им. академика Ж. Жеэнбаева НАН Кыргызской Республики, Кыргызстан, г. Бишкек, ${ }^{2}$ МежАународная лаборатория теоретической космологии, Томский государственный университет систем управления и радиоэлектроники (ТУСУР), Россия, г. Томск \\ ${ }^{3}$ Институт физики, О^денбургский университет, Германия, г. Олденбург, *e-mail: vfolomeev@mail.ru \\ Смешанные системы звезда плюс кротовая нора с комплексным скалярным полем
}

\begin{abstract}
Мы исследуем компактные смешанные конфигурации с нетривиальной топологией пространства-времени типа кротовой норы, образованные комплексным скалярным полем с четверичной потенциальной энергией и политропной жидкостью. ПослеАняя моделируется релятивистским баротропным уравнением состояния, которое может приближенно описывать более или менее реалистичное вещество. А^я таких систем мы находим регулярные асимптотически плоские равновесные решения, описывающие локализованные конфигурации, в которых жидкость сконцентрирована в области с конечными размерами. Полученные решения описывают кротовые норы с Авумя горловинами, которые расположены вне жидкости (можно сказать, что жидкость скрыта в области между горловинами). Также мы рассматриваем зависимость полной массы системы от центральной плотности жиАкости и демонстрируем существование критических значений центральной плотности, при которых масса расходится. При этом все регулярные решения с конечными массами лежат в области между критическими значениями, и эта область также содержит разрыв в значениях центральной плотности, в котором имеются только физически неприемлемые осцимлирующие решения. Показано, что А^я некоторых значений центральной плотности жилкости могут существовать решения, описывающие системы, в которых максимумы плотности жидкости и ее давления лежат не в центре конфигурации. Это приводит к тому, что такие системы обладают Авумя экваторами (^окальными максимумами метрической функции), расположенными симметрично относительно центра.
\end{abstract}

Ключевые слова: кротовые норы, нетривиальная топология, комплексные скалярные поля, политропная жиАКость.

\section{Introduction}

At the present time various scalar fields play an important role in constructing models of the early and present Universe. In particular, they may provide both the inflationary stage in the very early Universe and its current accelerated expansion [1]. Their role on small spatial scales comparable to sizes of galaxies and their clusters, as well as on scales of stars, can also be significant. Namely, one can imagine a configuration consisting of a scalar field confined by its own gravitational field - a boson star $[2,3]$. Due to the quantum Heisenberg uncertainty principle, there is a pressure inside such a star preventing it from gravitational collapse. In this sense such a scalar star is a sort of quantum-classical object whose existence is ensured simultaneously by quantum and classical properties of the scalar field. The studies performed in the literature indicate that masses of such objects can vary from atomic ones ("gravitational atom") to masses of the order of the Chandrasekhar mass, and even much larger. It is not impossible that there can be many such objects in the Universe. Then, if their electromagnetic radiation is weak, they can serve as candidates for the role of the missing dark matter.

In constructing models of boson stars, two types of scalar fields are used - real and complex ones [2, 3]. In doing so, usually a canonical field is employed with a fixed sign in front of the kinetic term of the scalar field Lagrangian density. If one takes the other sign, this corresponds to so-called ghost scalar fields. The possible existence of such fields in nature is indirectly supported by the observed accelerated expansion of the present Universe (see, e.g., Ref. [4]). As the canonical scalar fields, ghost fields enable one to get localized static nonsingular solutions both with a trivial spacetime topology [5] and with a nontrivial one - the so-called wormholes [6-10]. If ordinary matter or radiation can fill such wormholes, they are called traversable wormholes (for a general overview on the subject, see the books $[11,12])$. As matter threading the wormhole, one can use, for example, a relativistic fluid of the type containing in neutron stars. Then the mixed neutronstar-plus-wormhole configurations will possess properties of wormholes and of ordinary stars [1319]. 
The goal of the present paper is to study a wormhole supported by a complex ghost scalar field and filled with ordinary matter. To do this, we will construct localized regular solutions with a nontrivial wormholelike topology. In two limiting cases, such a system becomes the system consisting of a wormhole only (without ordinary matter) [20] or the mixed system supported by a massless real scalar field [16]. Our purpose will be to find out what are the differences between the configurations considered here and the systems of Refs. [16, 20].

\section{General equations}

We consider a model of a mixed gravitating configuration consisting of a complex ghost scalar field and polytropic fluid. The corresponding action for such a system can be taken in the form

$$
S=\int d^{4} x \sqrt{-g}\left\{-\frac{c^{3}}{16 \pi G} R+\frac{1}{2}\left[-g^{\mu \nu} \partial_{\mu} \Phi^{*} \partial_{\nu} \Phi-V\left(|\Phi|^{2}\right)\right]\right\}+S_{\mathrm{fl}},
$$

where $\Phi$ is a complex scalar field with the potential $V\left(|\Phi|^{2}\right)$ and $S_{\mathrm{fl}}$ denotes the action of the fluid. Hereafter the Greek indices run over $\mu, v \ldots=$ $0,1,2,3$.

By varying (1) with respect to the metric, one can obtain the gravitational equations whose right-hand side contains the energy-momentum tensor

$$
\begin{aligned}
& T_{v}^{\mu}=-\frac{1}{2} g^{\mu \sigma}\left(\partial_{\sigma} \Phi^{*} \partial_{v} \Phi+\partial_{\sigma} \Phi \partial_{v} \Phi^{*}\right)+ \\
&+\frac{1}{2} \delta_{v}^{\mu}\left(g^{\lambda \sigma} \partial_{\lambda} \Phi^{*} \partial_{\sigma} \Phi+V\right)+ \\
&+(\varepsilon+p) u^{\mu} u_{v}-\delta_{v}^{\mu} p
\end{aligned}
$$

where $\varepsilon$ is the energy density of the fluid and $p$ is its pressure. In turn, varying (1) with respect to the scalar field, one obtains the equation for $\Phi$,

$$
\begin{aligned}
& \frac{1}{\sqrt{-g}} \frac{\partial}{\partial x^{\mu}}\left[\sqrt{-g} g^{\mu \nu} \frac{\partial \Phi}{\partial x^{v}}\right]=\frac{d V}{d|\Phi|^{2}} \Phi . \backslash \\
& -\left[2 \frac{R^{\prime \prime}}{R}+\left(\frac{R^{\prime}}{R}\right)^{2}\right]+\frac{1}{R^{2}}=\frac{8 \pi G}{c^{4}} T_{0}^{0}=\frac{8 \pi G}{c^{4}}\left\{\varepsilon+\frac{1}{2}\left[-\left(\phi^{\prime 2}+\omega^{2} e^{-v} \phi^{2}\right)+V\right]\right\}, \\
& -\frac{R^{\prime}}{R}\left(\frac{R^{\prime}}{R}+v^{\prime}\right)+\frac{1}{R^{2}}=\frac{8 \pi G}{c^{4}} T_{1}^{1}=\frac{8 \pi G}{c^{4}}\left[-p+\frac{1}{2}\left(\phi^{\prime 2}+\omega^{2} e^{-v} \phi^{2}+V\right)\right], \\
& \frac{R^{\prime \prime}}{R}+\frac{1}{2} \frac{R^{\prime}}{R} v^{\prime}+\frac{1}{2} v^{\prime \prime}+\frac{1}{4} v^{\prime 2}=-\frac{8 \pi G}{c^{4}} T_{2}^{2}=-\frac{8 \pi G}{c^{4}}\left\{-p+\frac{1}{2}\left[-\left(\phi^{\prime 2}-\omega^{2} e^{-v} \phi^{2}\right)+V\right]\right\}, \\
& \phi^{\prime \prime}+\left(\frac{1}{2} v^{\prime}+2 \frac{R^{\prime}}{R}\right) \phi^{\prime}+\left(\omega^{2} e^{-v}+\frac{d V}{d|\Phi|^{2}}\right) \phi=0,
\end{aligned}
$$

where the prime denotes differentiation with respect to $r$. Depending on the specific form of the potential
$V$ and the boundary conditions, it is possible to obtain localized equilibrium solutions by solving 
these equations numerically. Notice here that in the absence of the fluid we return to the system of Ref. [20]. In turn, when $\omega=V=0$, we have the system of Ref. [16].

In order to obtain regular asymptotically flat solutions with a nontrivial topology, we take the potential

$$
V=-\frac{m^{2} c^{2}}{\hbar^{2}}|\Phi|^{2}+\frac{1}{2} \frac{\bar{\lambda}}{\hbar c}|\Phi|^{4},
$$

where $m$ and $\bar{\lambda}$ are free parameters of the scalar field.

Next, the above equations have to be supplemented by an equation of state for the fluid. We consider here the simplest case of a barotropic equation of state where the pressure is a function of the mass density $\rho$. Namely, we take the following polytropic equation of state that can approximately describe more or less realistic matter:

$$
p=K \rho^{1+1 / n}, \varepsilon=\rho c^{2}+n p,
$$

where the constant $K=k c^{2}\left(n_{b}^{(c h)} m_{b}\right)^{1-\gamma}$, the polytropic index $n=1 /(\gamma-1)$, and $\rho=n_{b} m_{b}$ denotes the rest-mass density of the fluid. Here $n_{b}$ is the baryon number density, $n_{b}^{(c h)}$ is a characteristic value of $n_{b}, m_{b}$ is the baryon mass, and $k$ and $\gamma$ are parameters whose values depend on the properties of the matter. For the sake of simplicity, we take here only one set of parameters $m_{b}=1.66 \times 10^{-24} \mathrm{~g}, n_{b}^{(c h)}=0.1 \mathrm{fm}^{-3}, k=0.1$, and $\gamma=2$ [21], and employ them in the numerical calculations of Sec. 3 .

Then, introducing the new variable $\theta$,

$$
\rho=\rho_{c} \theta^{n},
$$

where $\rho_{c}$ is the central density of the fluid, we can rewrite the pressure and the energy density from Eq. (7) as

$$
\begin{gathered}
p=K \rho_{c}^{1+1 / n} \theta^{n+1}, \varepsilon=\left(\rho_{c} c^{2}+n K \rho_{c}^{1+1 / n} \theta\right) \theta^{n} . \quad \text { rewrite Eqs. (2)-(5) in the form } \\
-\left[2 \frac{X^{\prime \prime}}{X}+\left(\frac{X^{\prime}}{X}\right)^{2}\right]+\frac{1}{X^{2}}=B(1+\sigma n \theta) \theta^{n}-\varphi^{\prime 2}-\Omega^{2} e^{-v} \varphi^{2}-\varphi^{2}+\frac{\Lambda}{2} \varphi^{4}, \\
-\frac{X^{\prime}}{X}\left(\frac{X^{\prime}}{X}+v^{\prime}\right)+\frac{1}{X^{2}}=-B \sigma \theta^{n+1}+\varphi^{\prime 2}+\Omega^{2} e^{-v} \varphi^{2}-\varphi^{2}+\frac{\Lambda}{2} \varphi^{4}, \\
\frac{X^{\prime \prime}}{X}+\frac{1}{2} \frac{X^{\prime}}{X} v^{\prime}+\frac{1}{2} v^{\prime \prime}+\frac{1}{4} v^{\prime 2}=B \sigma \theta^{n+1}+\varphi^{\prime 2}-\Omega^{2} e^{-v} \varphi^{2}+\varphi^{2}-\frac{\Lambda}{2} \varphi^{4},
\end{gathered}
$$




$$
\varphi^{\prime \prime}+\left(\frac{1}{2} v^{\prime}+2 \frac{X^{\prime}}{X}\right) \varphi^{\prime}+\left(\Omega^{2} e^{-v}-1+\Lambda \varphi^{2}\right) \varphi=0
$$

where $B=8 \pi G \lambda_{c}^{2} \rho_{c} / c^{2}$. Since, due to the Bianchi identities, not all of these equations are independent, one may use any three of them in calculations. Here, we will solve Eqs. (8), (10), (12), and (13), treating the first-order equation (11) as a constraint equation to check the accuracy of the computations.

When solving the above equations, we use the symmetric boundary conditions imposed at the center $x=0$,

$$
X(0)=X_{c}, v(0)=v_{c}, \varphi(0)=\varphi_{c}, \theta(0)=1
$$

(all first-order derivatives are supposed to be zero at the center). The constraint equation (11) then yields

$$
X_{c}=\frac{1}{\sqrt{\varphi_{c}^{2}\left(\Omega^{2} e^{\left.-v_{c-1+(\Lambda / 2)} \varphi_{c}^{2}\right)-B \sigma}\right.}} .
$$

Using this expression and expanding the function $X$ in the vicinity of the center as $X \approx$ $X_{c}+1 / 2 X_{2} x^{2}$, one can find from Eq. (10) the value of the second derivative of $X$ at the center

$$
X_{2}=\frac{X_{c}}{2}\left\{2 \Omega^{2} e^{-v_{c}} \varphi_{c}^{2}-B[1+\sigma(n+1)]\right\}
$$

Thus we have three parameters $-\varphi_{c}, v_{c}$, and $\Omega$, one of which can be chosen arbitrarily. For instance, as in the case of boson stars [22], as such a parameter, one can take $\varphi_{c}$. Then, the other two parameters should be chosen in such a way as to ensure asymptotic flatness of the spacetime, when $\varphi, \varphi^{\prime}$, and $v \rightarrow 0$ and $X \rightarrow x$. In this sense, we will deal with an eigenvalue problem for the parameters $v_{c}$ and $\Omega$.

It is also useful to write out the asymptotic behavior of the solutions:

$$
\begin{gathered}
e^{v} \rightarrow 1-\frac{2 C_{2}}{x}, X \rightarrow x, X^{\prime} \rightarrow 1-\frac{C_{2}}{x}, \\
\varphi \rightarrow C_{1} \exp \left(-\sqrt{1-\Omega^{2}} x\right) x^{\beta} \text { for } 0 \leq \Omega< \\
<1, \varphi \rightarrow C_{3} \frac{\exp \left(-\sqrt{8\left|C_{2}\right| x}\right)}{x^{\frac{3}{4}}} \text { for } \Omega=1,
\end{gathered}
$$

where $C_{1}, C_{2}$, and $C_{3}$ are integration constants and $\beta=-1+C_{2} \Omega^{2} / \sqrt{1-\Omega^{2}}$. Note that the integration constant $C_{2}$ plays the role of the Arnowitt-DeserMisner (ADM) mass of the wormhole-plus-fluid configurations under consideration.

We solve the set of equations (8) and (10)-(13) numerically, using the boundary conditions (14) and (15) and varying the value of the boson frequency $\Omega$ in the interval $0 \leq \Omega \leq 1$ [the lower limit $\Omega=0$ corresponds to the case of real scalar fields and the upper limit is the necessary condition to ensure a nonoscillating asymptotic behavior of the scalar field; see Eq. (17)]. In doing so, the systems under consideration may be subdivided into two regions: (i) the internal one, where both the fluid and the scalar field are present; (ii) the external one, where only the scalar field is present. Correspondingly, the solutions in the external region can be obtained from Eqs. (10)-(13), where the function $\theta$ is set to be zero. The internal solutions should be matched with the external ones at the edge of the fluid, $x=x_{b}$. This is done by equating the corresponding values of the functions $\varphi, X, v$ and their derivatives. The boundary of the fluid $x_{b}$ is defined by the condition $p\left(x_{b}\right)=0$. In turn, the integration constant $v_{c}$ can be determined from the

asymptotic solutions, proceeding from the requirement that the external solutions must be asymptotically flat.

In the left panels of figure 1, we show a set of typical solutions for the scalar field function $\varphi$, the fluid function $\theta$, and the metric function $v$. The value of the boson frequency $\Omega=1$ represents the limiting value of the physically acceptable interval. Note that for the chosen value $\varphi_{c}=0.5$ another limiting case $\Omega=0$ is undistinguishable since regular solutions do exist not for all $B$ but are restricted by some critical values of $B=B_{\text {crit }}$ (see below). An interesting feature of the system is the possibility of the presence of the maximum of the fluid density shifted with respect to the center of the configuration; see figure 1(a).

In the right panels of figure 1 , we exhibit the solutions for the metric function $X$. Its behavior strongly depends on the sign of the expansion coefficient $\Sigma_{2}$ from (16). Namely, for the given $\varphi_{c}=0.5$, the configurations always possess a double throat when the minimum value $X_{\text {th }}=$ $\min \{X(x)\}$ is on either side of the center of the configuration. In this case there are two possibilities: (i) if $X_{2}<0$, there is one equator (a 
local maximum of $X$ ); see figure 1(d); (ii) if $X_{2}>$ 0 , there may be already two equators located symmetrically with respect to the center; see figure 1(b). The existence of the double-equator systems is

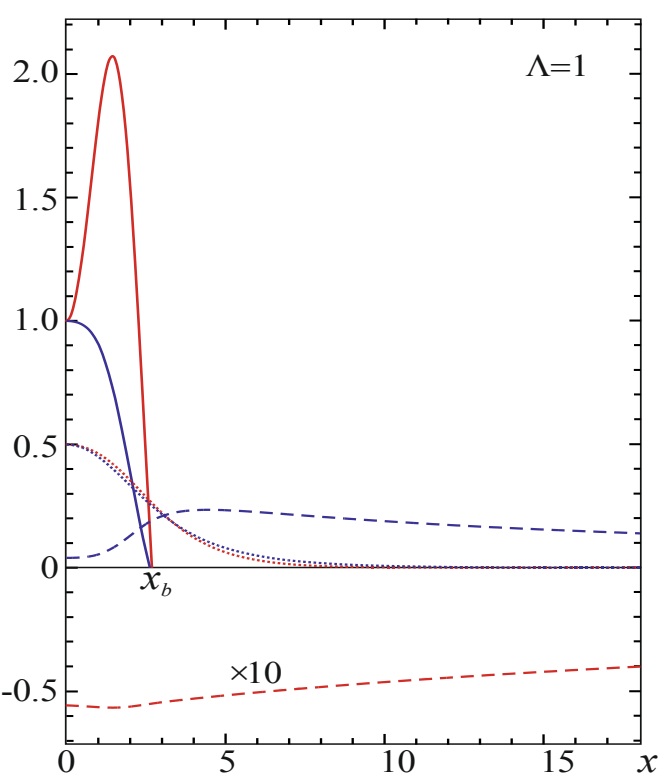

(a)

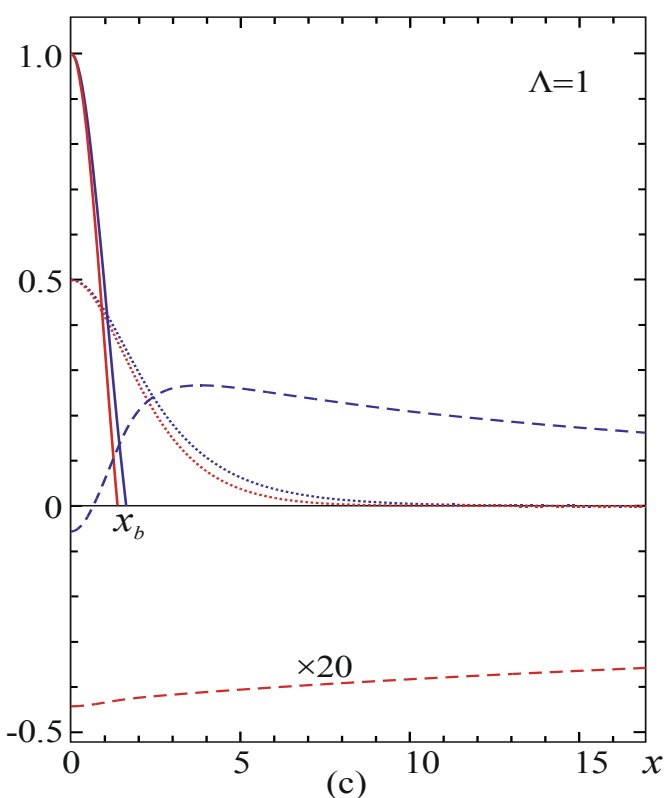

Figure 1 - Left panels: the scalar field function $\varphi$ (dotted lines), the fluid function $\theta$ (solid lines), and the metric function $v$ (dashed lines). Right panels: the graphs of the metric function $X$, where the positions of the throats $X_{\text {th }}=\min \{X(x)\}$ are shown by the bold dots. The shaded segments of the curves represent the regions where the fluid is present. The inset shows the asymptotic behavior when $X \rightarrow x$. For all plots, the blue curves correspond to the configurations with the limiting value $\Omega=1$,

the red curves are for the configurations with $\Omega \approx 0.058$ [ $B_{\text {crit } 1}$ : (a) and (b)] and with $\Omega \approx 0.013$ [ $B_{\text {crit2 }}$ : (c) and (d)].

The central value of the scalar field is taken to be $\varphi_{c}=0.5$. In view of the symmetry $x \rightarrow-x$, only the solutions for positive $x$ are shown. The numbers near the curves are the values of the corresponding scale factor introduced for convenience of representation. 


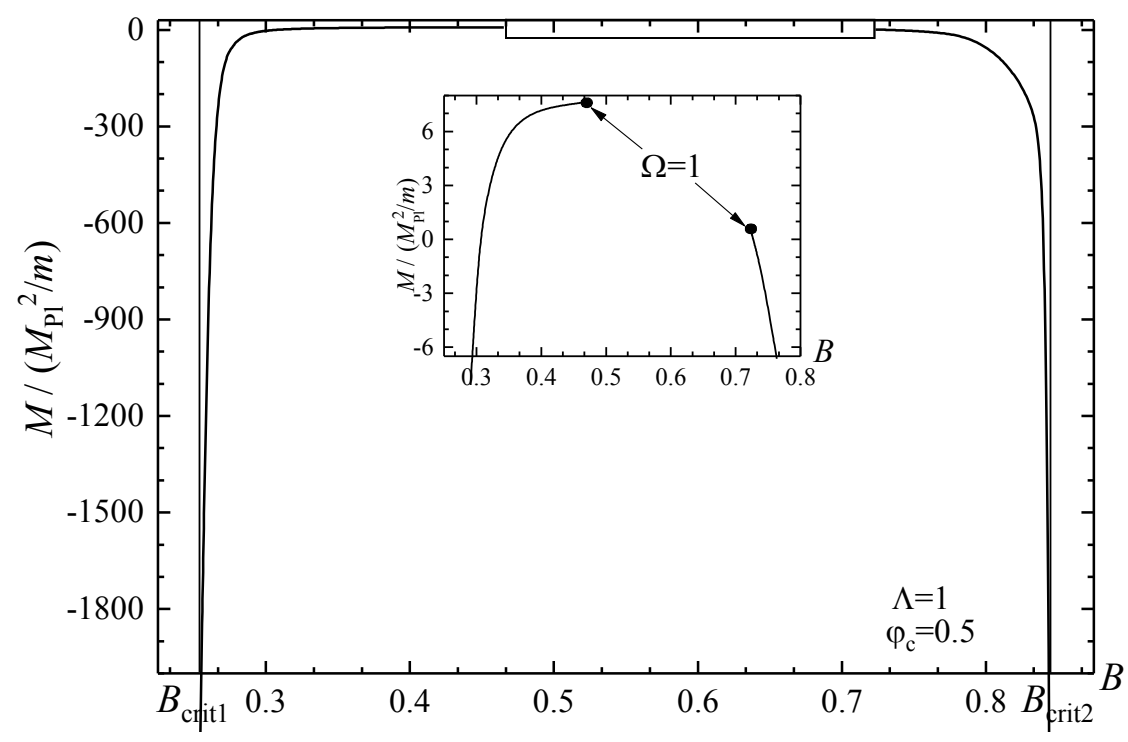

Figure 2 - The total mass of the configuration $M$ as a function of the parameter $B$.

The thin vertical lines correspond to $B=B_{\text {crit }}$ for which the mass of the configurations diverges (the corresponding solutions describing systems near these points are shown by red lines in figure 1 with $\Omega \approx 0.058$ for $B=B_{\text {crit } 1}$ and $\Omega \approx 0.013$ for $B=B_{\text {crit } 2}$ ). In the shaded region $\Omega>1$,

and the solutions for the scalar field are oscillating. The inset shows the region where the masses are close to zero.

For all cases considered here, the throats are located beyond the fluid, i.e., the fluid is completely hidden in the region between the throats. For other values of $\varphi_{c}$ one may expect both the existence of single-throat configurations and of systems with two throats filled with a fluid, as it takes place for the system of Ref. [16] supported by a real scalar field. But this issue requires special studies.

Let us now consider the ADM mass of the above systems. For a spherically symmetric configuration, the Misner-Sharp [23] mass $M(r)$ inside the volume enclosed by a sphere with circumferential radius $R_{c}$, which corresponds to the center of the system, and another sphere having the radius $R>R_{c}$, can be defined as follows:

$$
M(r)=\frac{c^{2}}{2 G} R_{c}+\frac{4 \pi}{c^{2}} \int_{R_{c}}^{r} T_{0}^{0} R^{2} d R .
$$

Taking the boundary to (spacelike) infinity, the Misner-Sharp mass gives the ADM mass. In the dimensionless variables (9), we then have

$$
M(x) \equiv \frac{M(x)}{\frac{M_{\mathrm{Pl}}^{2}}{m}}=\frac{1}{2}\left[X_{c}+\int_{0}^{x}\left[B(1+\sigma n \theta) \theta^{n}-\varphi^{\prime 2}-\Omega^{2} e^{-v} \varphi^{2}-\varphi^{2}+\frac{\Lambda}{2} \varphi^{4}\right] X^{2} \frac{d X}{d x^{\prime}} d x^{\prime}\right],
$$

where $M_{\mathrm{Pl}}$ is the Planck mass.

The results of the calculations of the mass are presented in figure 2. It is interesting to compare the results obtained with those found for wormholes supported by a real massless scalar and threaded by the same fluid [16]. Depending on the value of the parameter $B$, masses of those configurations can vary from 0 (for $B=0$ ) up to some finite positive magnitude for the critical value of $B=B_{\text {crit }}$. The existence of the latter follows from Eq. (15) and corresponds to the equality of the denominator to zero; as a result, $X_{c} \rightarrow \infty$. For the complex scalar fields considered in the present paper, we have not one but two

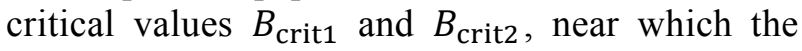
total mass of the configurations increases (modulus) rapidly and eventually diverges (see figure 2). In this case physically interesting solutions exist only for $B>B_{\text {crit1 }}$ and $B<$ $B_{\text {crit2 }}$, up/down to the values of $B$ for which the boson frequency $\Omega \rightarrow 1$ (see the inset of figure 2). Correspondingly, there is a discontinuity in 
possible values of $B$ (the shaded region in figure 2 where $\Omega>1$ ), where only asymptotically oscillating solutions for the scalar field do exist [cf. Eq. (17)].

\section{Conclusion}

We have considered mixed systems consisting of a complex ghost scalar field with a quartic potential and ordinary polytropic fluid. This study extends the previous researches of Refs. [16, 20] where the systems with a real massless scalar field plus a polytropic fluid [16] and the configurations supported by a complex ghost scalar field without ordinary matter [20] have been considered. We have shown that there exist static regular asymptotically flat solutions describing localized configurations in which the fluid is concentrated in a finite-size region. We have demonstrated that for the chosen central value of the scalar field (i) there exist only double-throat configurations; and (ii) the wormhole throats are located outside the fluid (or one can say that the fluid is hidden inside the region between the throats). Unlike the configurations of Ref. [16], the systems considered here possess the following new properties:

(1) Instead of one critical value $B_{\text {crit }}$, there are two different critical values $B_{\text {crit1 }}$ and $B_{\text {crit2 }}$ for which the total mass diverges. All regular solutions possessing finite masses lie in the region between these critical $B$ 's, and this region also contains a discontinuity in $B$ (shown by the shaded region in figure 2) where the boson frequency $\Omega>1$; this corresponds to the presence of oscillations of the scalar field, that is physically unacceptable.

(2) For some values of $B$, there can exist solutions describing systems whose fluid density and pressure maxima lie not at the center [see figure 1(a)]. This results in the fact that such systems possess two equators resided symmetrically with respect to the center; see figure 1(b).

The solutions obtained cover only a restricted set of the model parameters. In further investigations, we plan to extend these calculations. Moreover, it will be interesting to address their rotating generalizations [24].

\section{Acknowledgements}

We are grateful to the Research Group Linkage Programme of the Alexander von Humboldt Foundation for the support of this research. BK and JK gratefully acknowledge support by the DFG Research Training Group 1620 Models of Gravity and the COST Action CA16104.

\section{References}

1 Ade P.A.R. et al. (Planck Collaboration) Planck 2015 results. XIII. Cosmological parameters //Astron. Astrophys. - 2016. Vol.594:A13.

2 Schunck F.E. and Mielke E.W. General relativistic boson stars //Classical Quantum Gravity. - 2003. - Vol. 20. - P.R301.

3 Liebling S.L. and Palenzuela C. Dynamical Boson Stars //Living Rev. Relativity. - 2012. - Vol. 15. - P. 6.

4 Sullivan M. et al. SNLS3: Constraints on Dark Energy Combining the Supernova Legacy Survey Three Year Data with Other Probes //Astrophys. J. - 2011. - Vol.737. - P.102.

5 Dzhunushaliev V., Folomeev V., Myrzakulov R., and Singleton D. Non-singular solutions to Einstein-Klein-Gordon equations with a phantom scalar field //J. High Energy Phys. - 2008. - Vol.7:094. - 14 p.

6 Bronnikov K.A. Scalar-tensor theory and scalar charge //Acta Phys. Polon. - 1973. - Vol.B4. -P.251

7 Ellis H.G. Ether flow through a drainhole - a particle model in general relativity //Math. Phys. - 1973. - Vol.14. - P.104.

8 Ellis H.G. The Evolving, Flowless Drain Hole: A Nongravitating Particle Model In General Relativity Theory //General Relativ. Gravit. - 1979. - Vol.10. - P. 105.

9 Kodama T. General Relativistic Nonlinear Field: A Kink Solution in a Generalized Geometry //Phys. Rev. - 1978. - Vol.D18. - P.3529.

10 Kodama T., de Oliveira L.C.S., and Santos F.C. Properties of a general-relativistic kink solution //Phys. Rev. - 1979. Vol.D19. - P. 3576.

11 Visser M. Lorentzian Wormholes: From Einstein to Hawking. - New York: Woodbury, 1996. - 412 p.

12 Lobo F.S.N. Wormholes, Warp Drives and Energy Conditions. - Springer International Publishing Company, 2017. - 436 p.

13 Dzhunushaliev V., Folomeev V., Kleihaus B., and Kunz J. A Star Harbouring a Wormhole at its Core //J. Cosmol. Astropart. Phys. - 2011. - Vol.04:031. -22 p.

14 Dzhunushaliev V., Folomeev V., Kleihaus B., and Kunz J. Mixed neutron star-plus-wormhole systems: Equilibrium configurations //Phys. Rev. - 2012. - Vol.D85:124028. - 14 p.

15 Dzhunushaliev V., Folomeev V., Kleihaus B., and Kunz J. Mixed neutron-star-plus-wormhole systems: Linear stability analysis // Phys. Rev. - 2013. - Vol. D87:104036. - 12 p.

16 Dzhunushaliev V., Folomeev V., Kleihaus B., and Kunz J. Hiding a neutron star inside a wormhole //Phys. Rev. - 2014. Vol.D89:084018. $-14 \mathrm{p}$.

17 Aringazin A., Dzhunushaliev V., Folomeev V., Kleihaus B., and Kunz J. Magnetic fields in mixed neutron-star-plus-wormhole systems // JCAP. - 2015. - Vol.1504:005. - 23 p. 
18 Dzhunushaliev V., Folomeev V., and Urazalina A. Star-plus-wormhole systems with two interacting scalar fields // Int. J. Mod. Phys. - 2015. - Vol.D24. - P.14.

19 Dzhunushaliev V., Folomeev V., Kleihaus B., and Kunz J. Can mixed star-plus-wormhole systems mimic black holes? // JCAP. - 2016. - Vol.1608:030. - 27 p.

20 Dzhunushaliev V., Folomeev V., Kleihaus B., and Kunz J. Wormhole solutions with a complex ghost scalar field and their instability // Phys. Rev. - 2018. - Vol. D97:024002. - 10 p.

21 Salgado M., Bonazzola S., Gourgoulhon E., and Haensel P. High precision rotating netron star models 1: Analysis of neutron star properties // Astron. Astrophys. - 1994. - Vol. 291. - P. 155.

22 Colpi M., Shapiro S. L., and Wasserman I. Boson Stars: Gravitational Equilibria of Selfinteracting Scalar Fields // Phys. Rev. Lett. - 1986. - Vol.57. - P.2485.

23 Misner C. W. and Sharp D. H. Relativistic equations for adiabatic, spherically symmetric gravitational collapse // Phys. Rev. - 1964. - Vol.136. - P. B571.

24 Chew X. Y., Dzhunushaliev V., Folomeev V., Kleihaus B., and Kunz J. Rotating wormhole solutions with a complex phantom scalar field // Phys. Rev. - 2019. - Vol. D100:044019. - 12 p.

\section{References}

1 P.A.R. Ade et al. (Planck Collaboration), Astron. Astrophys., 594:A13 (2016).

2 Schunck F.E. and Mielke E. W. General relativistic boson stars //Classical Quantum Gravity. - 2003. - Vol. 20. - P.R301.

3 S.L. Liebling and C. Palenzuela, Living Rev. Relativity, 15, 6 (2012).

4 M. Sullivan et al., Astrophys. J., 737, 102 (2011).

5 V. Dzhunushaliev, V. Folomeev, R. Myrzakulov, and D. Singleton, J. High Energy Phys., 7:094 (2008).

6 K.A. Bronnikov, Acta Phys. Polon.B4, 251 (1973).

7 H.G. Ellis, Math. Phys., 14, 104 (1973).

8 H.G. Ellis, General Relativ. Gravit., 10, 105 (1979).

9 T. Kodama, Phys. Rev. D18, 3529 (1978).

10 T. Kodama, L.C.S. de Oliveira, and F.C. Santos, Phys. Rev. D19, 3576 (1979).

11 M. Visser, Lorentzian Wormholes: From Einstein to Hawking, (Woodbury, New York, 1996), 412 p.

12 F.S.N. Lobo Wormholes, Warp Drives and Energy Conditions, (Springer International Publishing Company, 2017 ), 436 p.

13 V. Dzhunushaliev, V. Folomeev, B. Kleihaus, and J. Kunz, J. Cosmol. Astropart. Phys., 04:031 (2011).

14 V. Dzhunushaliev, V. Folomeev, B. Kleihaus, and J. Kunz, Phys. Rev. D85:124028 (2012).

15 V. Dzhunushaliev, V. Folomeev, B. Kleihaus, and J. Kunz, Phys. Rev. D87:104036 (2013).

16 V. Dzhunushaliev, V. Folomeev, B. Kleihaus, and J. Kunz, Phys. Rev. D89:084018. (2014).

17 A. Aringazin, V. Dzhunushaliev, V. Folomeev, B. Kleihaus, and J. Kunz, JCAP, 1504:005 (2015).

18 V. Dzhunushaliev, V. Folomeev, and A. Urazalina, Int. J. Mod. Phys. D24, 14 (2015).

19 V. Dzhunushaliev, V. Folomeev, B. Kleihaus, and J. Kunz, JCAP, 1608:030 (2016).

20 V. Dzhunushaliev, V. Folomeev, B. Kleihaus, and J. Kunz, Phys. Rev. D97:024002 (2018).

21 M. Salgado, S. Bonazzola, E. Gourgoulhon, and P. Haensel, Astron. Astrophys., 291, 155 (1994).

22 M. Colpi, S.L. Shapiro, and I. Wasserman, Phys. Rev. Lett., 57, 2485 (1986).

23 C.W. Misner and D.H. Sharp, Phys. Rev. 136, B571 (1964).

24 X.Y. Chew, V. Dzhunushaliev, V. Folomeev, B. Kleihaus, and J. Kunz, Phys. Rev. D100:044019 (2019). 